\title{
Influence of seagrass meadows on predator-prey habitat segregation in an Adriatic lagoon
}

\author{
S. T. Schultz ${ }^{1, *}$, C. Kruschel, T. Bakran-Petricioli ${ }^{2}$ \\ ${ }^{1}$ University of Zadar, Ulica M. Pavlinovic̀a bb, 23000 Zadar, Croatia \\ ${ }^{2}$ Division of Biology, Faculty of Science, University of Zagreb, Rooseveltov trg 6, 10000 Zagreb, Croatia
}

\begin{abstract}
Seagrass meadows have been hypothesized to protect mobile macrofauna from predation by providing structural complexity that interferes with predator movement and vision. However, if ambush predators are common in seagrass, they may exclude many prey species, resulting in lower total abundance and diversity in seagrass relative to neighboring bare substrates, and segregation of predators and their prey into different habitats. We tested these abundance and diversity predictions using visual censuses of fish and invertebrates employing georeferenced videography to quantify habitat and pinpoint every observation, and using bait stations and drop nets over $38 \mathrm{~km}$ of scuba transects in all 4 seasons and by day and night in an enclosed estuary of the northeast Adriatic (Novigrad Sea, Croatia). The primary fish predators at our study site were the ambush or stalk-attack predators, grass goby Zosterisessor ophiocephalus and European eel Anguilla anguilla, and we found that these species strongly preferred seagrass habitat. In contrast, most other fish, including small juveniles, avoided seagrass and preferred bare sediment to vegetated habitats. Species strongly preferring seagrass were primarily sessile invertebrates not preyed on by the goby or eel. Both total macrofaunal density and total taxon richness were greatest on bare sediment and lowest in dense seagrass habitats. The 3-dimensional aspect of habitat structure was as important in delineating the communities as the presence or absence of habitat structure. These results are consistent with the hypothesis that ambush predators reduce the value of seagrass habitat for their prey relative to neighboring bare sediment or rock; that structured habitat might carry a higher mortality risk for many prey species, and that neighboring unvegetated habitat, including bare sediment, can be at least as important as seagrass in harboring biodiversity.
\end{abstract}

KEY WORDS: Seagrass $\cdot$ Predation $\cdot$ Habitat structure $\cdot$ Abundance $\cdot$ Diversity $\cdot$ Adriatic

\section{INTRODUCTION}

Seagrass meadows have been shown to provide many features of value to shallow coastal ecosystems, including important habitat for mobile macrofauna (Larkum et al. 2006). In a detailed review of Australian research, Bell \& Pollard (1989, p 569) conclude 'Seagrass beds are generally better habitats for fish than bare substrata, i.e. a greater number of fish species and individuals occur in seagrasses' and this perception has been cited in recent reviews of the importance of seagrass as a habitat for commercial fish and invertebrates (Jackson et al. 2001, Gillanders 2006) and as a nursery habitat for juvenile animals in general (Beck et al. 2001, Heck et al. 2003).
The Heck \& Orth (1980) model posits that the major proposed habitat benefit of seagrass is the refuge from predation provided by 3 -dimensional structural complexity: the capture success of predators is proposed to be generally higher over bare substrates, leading to the evolution of avoidance behavior of less complex habitats by settling larvae, juveniles, and adults (Heck \& Orth 1980, Orth et al. 1984, Bell \& Westoby 1986, Bell \& Pollard 1989, Heck et al. 2003, Heck \& Orth 2006). Other possible benefits have been proposed but have generally received less empirical support; thus (Heck et al. 2003, p 133) state that 'In aggregate, we believe that the evidence indicates that the factor most often limiting animal populations in shallow coastal 
water is the shelter from predators that structured habitats provide'.

However, predation risk is mediated by the mode of predation and the numerical response of predators and prey. While seagrass has been shown to reduce the predation efficiency of chase-attack predators, the efficiency of stalk-attack predators or ambush predators might be improved by structural complexity and the ambush cover it provides (Heck \& Orth 1980, Horinouchi 2007b). Hence, we propose a more general predation-mode model: the relative value of seagrass as predation cover depends on the relative abundance of ambush-, stalk- and chase-attack predators inhabiting seagrass and neighboring substrata. For example, in regions where ambush predators are common inhabitants of seagrass, they may exclude potential prey and reduce the total abundance and diversity of mobile species in the seagrass habitat.

To investigate these predictions, we censused fishes and invertebrates in geo- and video-referenced scuba belt transects in a shallow Mediterranean lagoon in which numerous habitats were well represented and intermixed, including 3 categories of 3-dimensional structure (seagrass, macroalgae, and rock substratum from cobble to boulders and sculpted sedimentary bedrock) in addition to regions of unvegetated, mostly homogeneously mixed sand and gravel (up to about $1 \mathrm{~cm}$ diameter) ranging in patch diameter from $<1$ to $\sim 50 \mathrm{~m}$. Simultaneous sampling and quantification of a natural mosaic of structured and unstructured habitats, including seagrass at different densities, all in close proximity and freely available to animal inhabitants, allows strong inference of the relative preferences of individual species for these habitats (La Mesa et al. 2006). Several functional groups of predatory fish inhabit the sampling area, particularly 2 common species of ambush or stalk-attack predators, the European eel Anguilla anguilla and the grass goby Zosterisessor ophiocephalus, which are known to reside within seagrass beds where they feed opportunistically on fish and invertebrates (Pagotto \& Campesan 1980, Malavasi et al. 2005, Bouchereau et al. 2006, Ribeiro et al. 2006).

We posed the following major questions: (1) What are the relative density and species richness of all macrofauna within neighboring seagrass (dense and sparse), rock, macroalgae, and bare sediment habitat? (2) What taxa have significant positive or negative preferences for these habitats at scales comparable to their daily movements, and do these preferences predict abundances on a wider scale? (3) Are taxonomic aggregations delineated primarily by the presence/absence of structure, or primarily by the kind of structure? (4) Do major predators of fish and their known prey segregate into different habitats?

\section{MATERIALS AND METHODS}

Study area. The Novigrad Sea, Croatia $\left(44^{\circ} 12^{\prime} \mathrm{N}\right.$, $15^{\circ} 30^{\prime} \mathrm{E}$ ), is a protected estuarine embayment of $29 \mathrm{~km}^{2}$ (approximately $8 \times 5 \mathrm{~km}$ at its longest axes) in the eastern Adriatic Sea, connected to the Velebit Channel to the north by a narrow strait (the Maslenica Channel), and receiving freshwater inflow from the Zrmanja River to the northeast, underground springs, and a few small seasonal creeks (Sinovćić et al. 2004, MatićSkoko et al. 2007, Fig. 1). Shallow benthic habitats (less than about $5 \mathrm{~m}$ depth) include dense macroalgae/rock, unconsolidated bare sediment, and sparse to dense seagrass on soft sediment especially in the low gradient western portion near Posedarje. Salinity in the sampled region varied from 25 to 39 psu and surface temperatures from 9 to $26^{\circ} \mathrm{C}$, with temperatures below $2 \mathrm{~m}$ depth usually 2 to $3^{\circ} \mathrm{C}$ cooler.

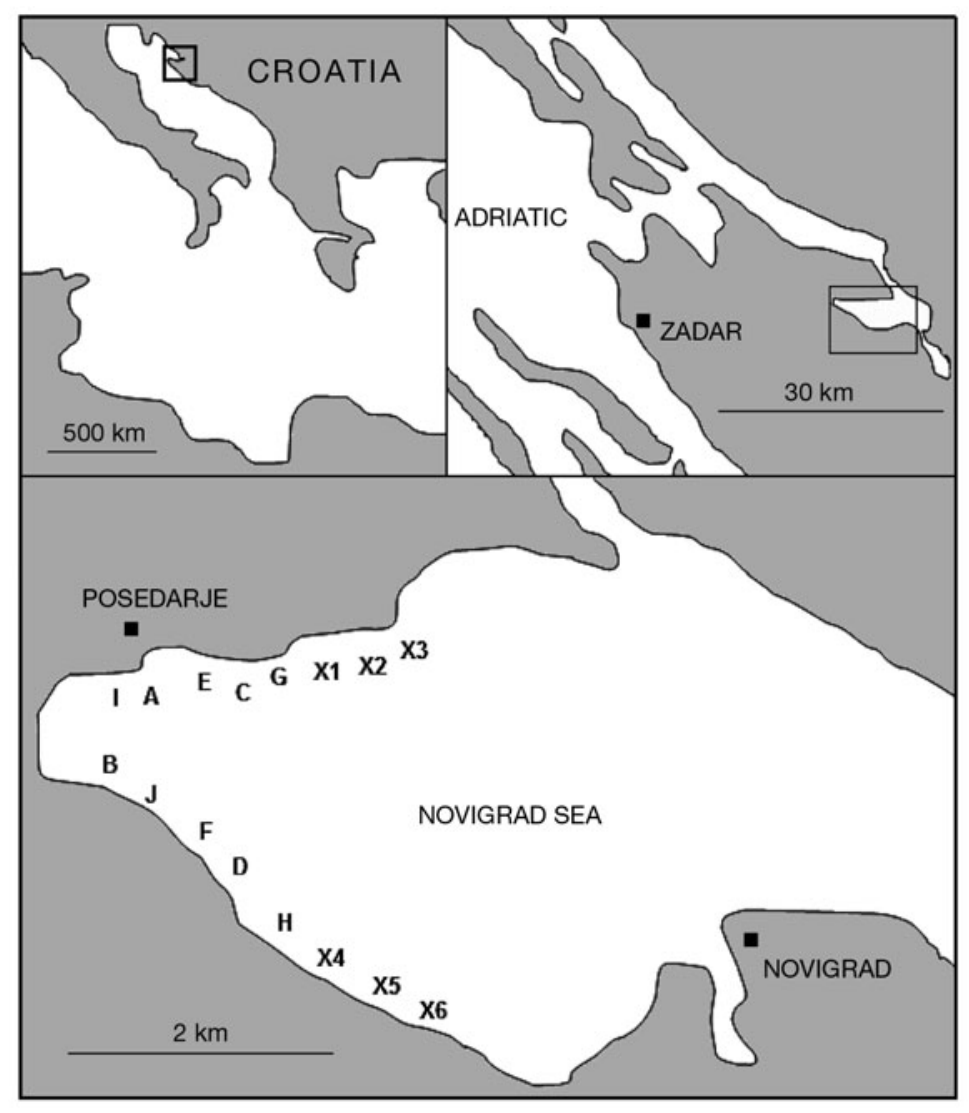

Fig. 1. Approximate location of the 10 sampling sites (A-J) in the Novigrad Sea, Croatia. X1 to X6 refer to sites where seagrass is completely absent 
The study location was chosen for its known value as a nursery area for demersal fish and invertebrates (Matić-Skoko 2007) and for the presence of equal amounts of bare sediment and each of the major structured benthic habitats of shallow protected waters of the Adriatic (seagrass, rock from cobble to bedrock, and macroalgae), all intermixed and within close proximity of each other along a shoreline several kilometers in length.

Visual census. The abundance of macrofauna was recorded within $2 \mathrm{~m}$ wide scuba belt transects (Nagelkerken et al. 2000, Horinouchi et al. 2005). Visual census allows the quantification of small-scale habitat occupation by each individual in all habitats and down to the scale of body size, which is not possible for other popular census methods such as trawl or seine sampling (Gray et al. 1998, Hindell \& Jenkins 2005, Horinouchi et al. 2005). Macrofauna censused comprised all fish species and all living invertebrates larger than approximately $1 \mathrm{~cm}$ in major dimension (size was esimated visually). Species were recorded in observational units (OU) labeled 'groups,' defined as recognizable spatial clusters of $>1$ individual. For each species in each group, the actual number of individuals to 20 was counted, and numbers higher than 20 were estimated in increments of 10 to a group size of 100, then in increments of 100 to the maximum observed group size of 1000. Transects were followed at a speed of approximately $0.3 \mathrm{~m} \mathrm{~s}^{-1}$ during the day and $0.15 \mathrm{~m} \mathrm{~s}^{-1}$ at night. Transect length ranged from $10 \mathrm{~m}$ ('short transects') to over $300 \mathrm{~m}$ ('long transects').

Spatiotemporal sampling. The western corner of the Novigrad Sea was sampled in summer and fall 2006, and winter, spring, and fall 2007. The sampled region comprised approximately 5.0 linear $\mathrm{km}$ of shoreline from a depth of 0.5 to $5 \mathrm{~m}$, and encompassed a total sampling area of approximately 100 ha (Fig. 1). The region was composed of 2 sampling strata: a western stratum containing seagrass meadows and an eastern stratum completely lacking seagrass meadows. Sampling sites were chosen randomly within each of these 2 strata.

At each site, visual census transects were followed within each of 3 habitat/depth 'zones': (1) predominately macroalgae/rock (0.5 to $2 \mathrm{~m})$, (2) transitional, predominately bare sediment or rock with sparse or absent algae or seagrass (2 to $3 \mathrm{~m}$ ), and (3) dense or sparse seagrass (2 to $5 \mathrm{~m}$ ). In the eastern sampling stratum, this deep zone entirely lacked seagrass. While the name of each zone reflects its modal bottom habitat, the benthos was heterogeneous and all 5 habitats (algae, bare sediment, rock, dense seagrass, and sparse seagrass) in reality occurred in patches within each zone. Algal species present were primarily Cystoseira spp. and Fucus spp. Seagrass species observed were Zostera marina, Z. noltii, and Cymodocea nodosa. All 3 depth zones at each location were usually sampled within a single $24 \mathrm{~h}$ period during daylight (at least $3 \mathrm{~h}$ after dawn and before sunset) and at night (usually less than $3 \mathrm{~h}$ after sunset, using a $6 \mathrm{~W}$ focused LED beam).

In summer/fall 2006, short transects were used to census fish and cephalopod abundance at 31 random sampling sites: 25 in the western seagrass stratum and 6 in the eastern non-seagrass stratum. For this approach, a random point was chosen in each of the 3 spatial strata (macroalgae, seagrass, and transition) at each site, and three $10 \mathrm{~m}$ transects were followed in random directions starting at 2 to $5 \mathrm{~m}$ from each random point during the day and at night within a single $24 \mathrm{~h}$ period.

In winter 2006, spring 2007, and summer/fall 2007 , long transects were used to continue monitoring fish and invertebrate abundance, day and night, in the 3 habitat zones at a total of 10 sampling sites ( 5 on each side of the estuary), all within the western seagrass stratum (Fig. 1). Transects ranged from 100 to $>300 \mathrm{~m}$ in length (limited by breathing-air) and crossweaved through each zone at an angle of approximately $45^{\circ}$ from the shoreline. Macrofaunal observations were made as in the short transects, but in addition the satellite time to seconds of each OU was recorded, along with the bottom type associated with that specific OU, to cross reference with the differential global positioning system (DGPS) data and accompanying video of the habitat at the time of observation.

DGPS/videography. During the daytime long-transect sampling, the diver carried a video sensor (Sony, 480 color TVL) that continuously recorded the sea bottom. The sensor was attached to 2 parallel laser diodes separated by a fixed distance of $12 \mathrm{~cm}$ to provide a continuous scale reference. Simultaneously overlayed on the video image was satellite time recorded every 2 s. Depth was recorded by a $200 \mathrm{kHz}, 11^{\circ}$, singlebeam transducer. Horizontal DGPS coordinates were taken with real-time sub-meter accuracy from radio transmissions to a GPS antenna held by an operator in a kayak directly above the video sensor, which was visible from the surface (Norris et al. 1997, Dauwalter et al. 2006, Schultz 2008). The night dives followed the same transects as the day dives, by sub-meter realtime navigation over the DGPS tracks of that day's dive transects. No underwater survey markers or tape measures were used in the video-monitored transects as these were observed to attract fish in trials.

The proportion of each transect classified exclusively as algal/rock (A), 'unstructured' (bare sediment, U), bare rock $(\mathrm{R})$, dense seagrass (SD), or sparse seagrass (SS) habitat was determined from the video footage. This was accomplished by assigning each second of 
the video footage exclusively to one of these habitat types and then calculating the linear extent of the transect occupied by each of these 5 habitats from the associated DGPS positions (Schultz 2008). Unstructured sediment was defined as lacking 3-dimensional structure above about $1 \mathrm{~cm}$ in relief, rock as particles larger than $6.4 \mathrm{~cm}$ in diameter, and dense seagrass by complete coverage of the habitat in the video frame. The map resolution of this classification was approximately $0.3 \mathrm{~m}$, the mean distance traveled per second of dive transect.

Drop nets and bait stations. In addition to the visual censuses, fishes were sampled or observed in $\mathrm{U}$ and in SD or SS habitats with unbaited, weighted drop nets $(1 \times 1 \mathrm{~m}$, Douglas Net Company) and bait stations (selfmade) in June 2008. In preliminary visual trials, the drop nets were highly effective in catching small benthic fish where they were present, including small juveniles of several species. A total of 220 net drops were carried out, 110 in SD/SS and 110 in U habitats, equally divided across the 10 study sites of the visual censuses.

The bait stations consisted of pins to which a piece of light-colored, raw fish tissue $(1 \times 1 \mathrm{~cm}$ piece $)$ was fixed $5 \mathrm{~cm}$ above the sediment surface. A scuba diver visually observed and recorded all visitors of all species approaching the bait over a 5 min period immediately following its placement. A total of 26 bait stations were observed with 3 replicates at each station, and stations were equally divided between $\mathrm{U}, \mathrm{SS}$ and SD habitats.

Data analysis. Abundance was analyzed with generalized linear statistical models (GLMs) that assumed quasibinomial or quasipoisson dispersion for individual species, and quasipoisson or gaussian dispersion for all species combined. The covariates were Sampling site (random), and Depth and Season of sampling (fixed), and abundance was expressed as the number of observations (individuals or groups) in a particular habitat type or depth zone divided by the total length of that habitat or depth zone at the sampling site. In all cases, the null hypothesis of no relation between predictor variable and animal occurrence was tested by a likelihood-ratio chi-square statistic comparing the 2 nested mixed models with and without the predictor variable (Solana-Sansores 2001). Analyses were generally conducted twice, using individuals or groups as the response variable. Ninety-eight percent of all groups were comprised of 10 individuals or less. Numbers of both individuals and groups are presented for the sake of completeness. For statistical tests, the appropriate unit of replication is probably the group, since individuals within a group are not independent observations. Differences in results between the 2 types of test, however, were small.
Species richness was the total count of taxa observed at each habitat. Species diversity was calculated as the Simpson reciprocal index $\mathrm{D}=1 / \sum p_{\mathrm{i}}^{2}$ where $p_{\mathrm{i}}$ is the relative density of taxon $i$ at that habitat (Hill 1973). Non-parametric bootstrap procedures were used to extrapolate total species richness and for hypothesis testing (Palmer 1990).

Habitat selection of a taxon was defined as a significant departure from random distribution in observations of the taxon in a given habitat (Rhodes et al. 2005). Habitat selection was quantified with the 'habitat selection ratio' $R=\rho_{\text {in }} / \rho_{\text {out }}$, where $\rho_{\text {in }}$ is the sample proportion of $0.3 \mathrm{~m}$ transect segments that contain the taxon inside a focal habitat and $\rho_{\text {out }}$ is the same proportion for all available habitats outside the focal habitat but within the local sampling site (Cairns \& Telfer 1980, Gras \& Saint-Jean 1982). This ratio can also be thought of as the abundance ratio in/out scaled by the ratio of available habitat in/out. The proportion $\rho$ estimates the probability that a small segment of a habitat contains the taxon, and a significant $\mathrm{R}>1$ implies a higher probability of occupation of a random segment within the habitat than of a random segment outside of that habitat. By definition, this difference constitutes positive selection of the habitat. Habitats with significant $\mathrm{R}>1$ or $\mathrm{R}<1$ were labelled 'favored' or 'avoided' habitats, respectively. The habitat with maximum $\mathrm{R}$ was defined as the 'preferred' habitat. Note that habitat selection as defined here is context-dependent; e.g. positive selection for one habitat necessarily lowers $\mathrm{R}$ values for other available habitats, regardless of whether those habitats would be avoided in the absence of the preferred habitat.

Species/ground association cluster analysis was performed on mean standardized species abundance per transect meter of each ground cover or habitat observed (A, R, SD, SS, and U) across all sites and sampling times pooled, and only species encountered on over 5 occasions were included in the analysis. Probability values for hierarchical clusters were computed by multiscale bootstrap resampling, with $p=0.95$ as the threshold defining a strongly supported cluster (Suzuki \& Shimodaira 2006). Clusters were agglomerated using a variety of methods and distances; since these yielded only minor differences, results are reported for the complete agglomeration method and euclidean distance. Species/grounds ordination was performed with detrended correspondence analysis (DCA) and Kruskal's non-metric multidimensional scaling with Bray-Curtis distances; because the 2 yielded very similar ordinations, only the DCA is reported.

Feeding behavior for each fish species was acquired from the database Fishbase (Froese \& Pauly 2000), which allowed the feeding guild information of Elliott \& Dewailly (1995) to be approximately quantified. For 
each species, information from all published studies of feeding behavior was combined and a proportion was assigned for each category of prey item (nekton, zoobenthos, plankton, and vegetation) of that species. The mean proportion of each prey category for each habitat was computed as a weighted mean prey proportion across all predators, where the weights were the relative abundance of each predator in that habitat.

The effects of habitat on faunal aggregations was tested using an analysis of similarity (ANOSIM, Clarke 1993), and distinctiveness of each habitat contrasted with all other habitats was determined. The effect of predator on prey aggregation was tested with a nonparametric Mantel test comparing the distance matrices of fish predator and prey abundance on the habitats sampled within each site (Legendre \& Legendre 1998). The effect of total fish predator density on fish prey aggregations was tested with non-parametric multivariate analysis of variance (MANOVA) (Anderson 2001). Prey were defined as any group of juvenile fish less than $5 \mathrm{~cm}$ long or consisting of Atherina. Prey was dominated by species of Gobidae (genera Gobius or Pomatoschistus). Small Gobidae and Atherina are frequently cited as prey specifically of Anguilla anguilla (Costa 1988) and Zosterisessor ophiocephalus (Miller 1986 ) in the published literature from our study region, and we also observed $Z$. ophiocephalus feeding routinely and repeatedly on these species in ongoing tank experiments (results not shown).

\section{RESULTS}

\section{Overall abundance}

A total of 61713 individuals (54 043 fishes and 7670 invertebrates) grouped in 14668 OU (10 359 fish and 4309 invertebrate) and comprising a minimum of 85 taxa (39 fishes and 46 invertebrates) were observed and recorded along a total of $38.666 \mathrm{~km}$ of dive transects traversed in $60 \mathrm{~h}$. Total density was thus 1.6 ind. transect $\mathrm{m}^{-1}$ (1.4 fish and 0.20 invertebrates), or 0.38 OU transect $\mathrm{m}^{-1}$ ( 0.27 fishes and 0.11 invertebrates). Because each transect meter equals $2 \mathrm{~m}^{-2}$ of observed ground, these densities are double the density per square meter.

\section{Benthic habitats}

Long transects intercepted a total of $5930 \mathrm{~m}$ of habitat type A, $5500 \mathrm{~m}$ of R, $9300 \mathrm{~m}$ of SD, $9400 \mathrm{~m}$ of SS, and $8400 \mathrm{~m}$ of $\mathrm{U}$, with each category being scored at a resolution of about $0.3 \mathrm{~m}$. All seagrass populations occurred on unconsolidated sediment and all algal habitat occurred on rock. The sampling sites featured different proportions of these habitats, averaged across all 3 depth zones.

\section{Abundance by habitat type}

Abundances per linear meter (ind. transect $\mathrm{m}^{-1}$ ) of ground cover or habitat at a long-transect sampling site varied significantly across habitat types (Fig. 2). Fish were most abundant in $\mathrm{A}, \mathrm{U}$, and $\mathrm{R}$, and least abundant in SD and SS (individuals: $\chi_{4}^{2}=16.4, \mathrm{p}=$ 0.0025, groups: $\chi_{4}^{2}=31.5, \mathrm{p}=2.4 \times 10^{-6}$ ); invertebrates were about equally abundant in all habitats, although groups were slightly more abundant in SS than in SD (individuals: $\chi_{4}^{2}=2.9, \mathrm{p}=0.57$, groups: $\chi_{4}^{2}=12.7, \mathrm{p}=$ 0.012), while the totals showed a lower abundance in seagrass, due primarily to the fish subset (individuals: $\chi_{4}^{2}=16.1, \mathrm{p}=0.0028$; groups: $\chi_{4}^{2}=20.9, \mathrm{p}=0.00033$ ).

Results of the drop net and bait-station experiments corroborated the lower fish densities observed in SD and $\mathrm{SS}$ relative to $\mathrm{U}$ habitats in the visual censuses. In 220 drop nets, the mean number of fish caught in $U$ and SD and SS habitats was 0.76 and 0.0091 , respectively. This difference was very highly significant (analysis of deviance $D_{1,208}=107, \mathrm{p}=1 \times 10^{-31}$ ). Species caught in U habitats were Gobius niger, Syngnathus spp., juvenile Gobius, Symphodus cinereus, and Pomatoschistus minutus, while the only species caught in SD or SS on rare occasions was G. niger. Eels and the grass goby were not catchable in the drop nets as they appeared to avoid them easily.

The mean numbers of individuals visiting the bait stations in U, SS and SD habitats were 12, 4.7, and 1.8, respectively. These differences were again very highly significant (analysis of deviance $D=77_{2,23}, \mathrm{p}=6.4 \times$ $10^{-8}$; Fig. 3). The most abundant visitors in U were Gobius niger and juvenile Gobius, while the only regular visitor at SD was the grass goby Zosterisessor ophiocephalus.

\section{Abundance by ground structure}

Abundance differences were less pronounced across benthic habitat types after re-categorization by presence/absence of 3-dimensional structure, defined as vegetation (seagrass or algae) or rock (Fig. 4). While abundance of individuals differed little across these categories, abundance of groups of fish was significantly greater over unvegetated and unstructured ground habitat (unvegetated: $\chi_{1}^{2}=32.6, \mathrm{p}=1.1 \times 10^{-8}$; unstructured: $\left.\chi_{1}^{2}=28.1, \mathrm{p}=1.1 \times 10^{-7}\right)$, resulting in parallel differences in total animal group abundance (unvegetated: $\chi_{1}^{2}=20.0, \mathrm{p}=7.9 \times 10^{-6}$; unstructured: $\left.\chi_{1}^{2}=22.3, \mathrm{p}=2.3 \times 10^{-6}\right)$. 


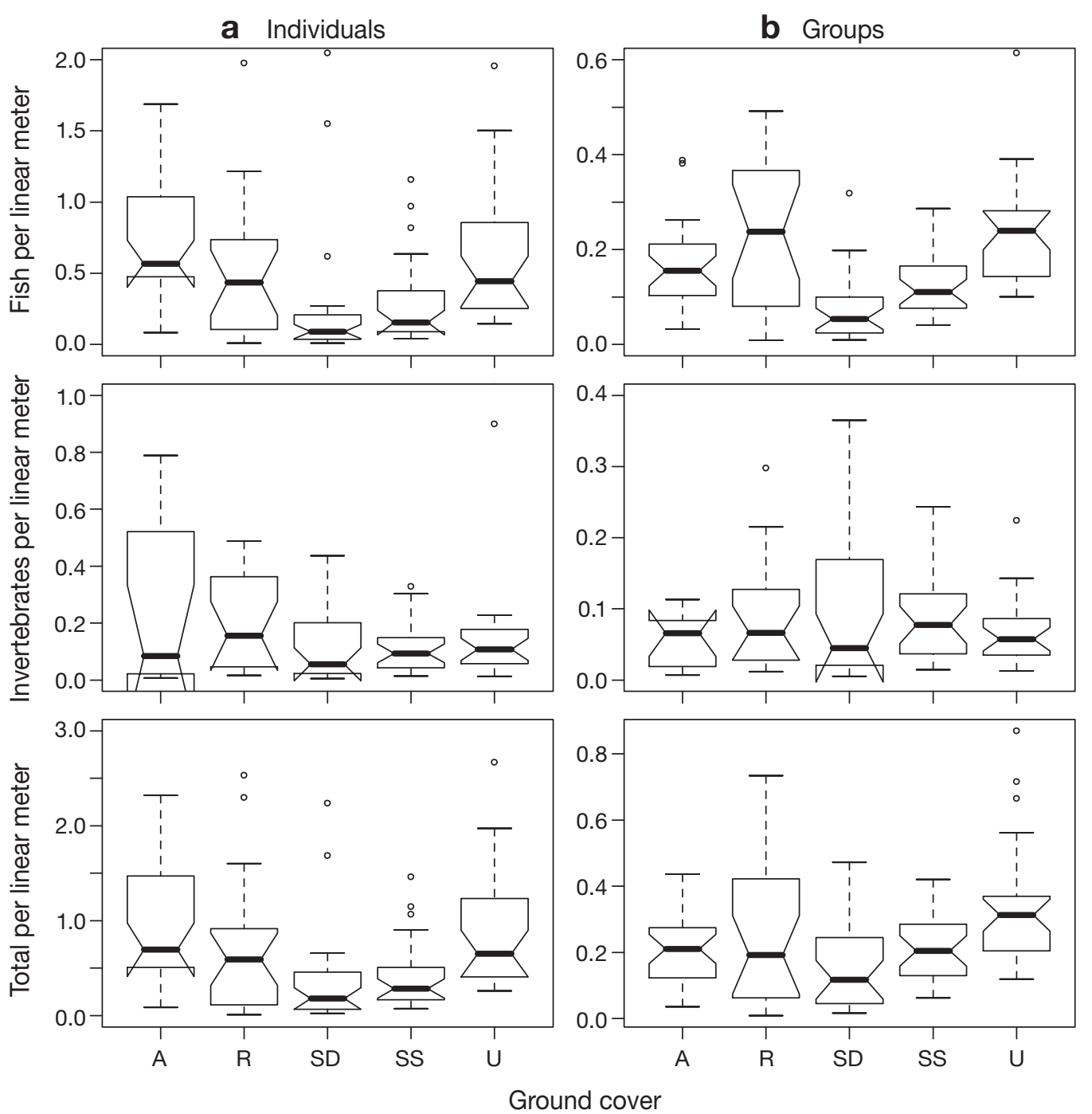

Fig. 2. Boxplots of number of (a) individuals or (b) groups per transect meter of habitat type: macroalgae (A), rock (R), dense seagrass (SD), sparse seagrass (SS), or unstructured bare sediment (U)

\section{Taxon richness and diversity}

Habitat types fell into 2 groups within which taxon richness was not significantly different: unvegetated or sparsely vegetated (R/U/SS) versus more densely vegetated (SD/A); on average, a habitat in the former group had $40 \%$ more taxa (Fig. 5). Primarily because of the high species richness in $U$, there were no significant differences between habitats re-categorized as vegetated/unvegetated (67/67 observed taxa), structured/unstructured (73/57), seagrass/non-seagrass (64/ $70)$, or seagrass/unstructured (64/57). The large difference between structured and unstructured is attributable to the larger extent of structured substrate examined and hence the greater total number of observations; the difference between the 2 curves was not significant ( $p=0.45$, Fig. 5).

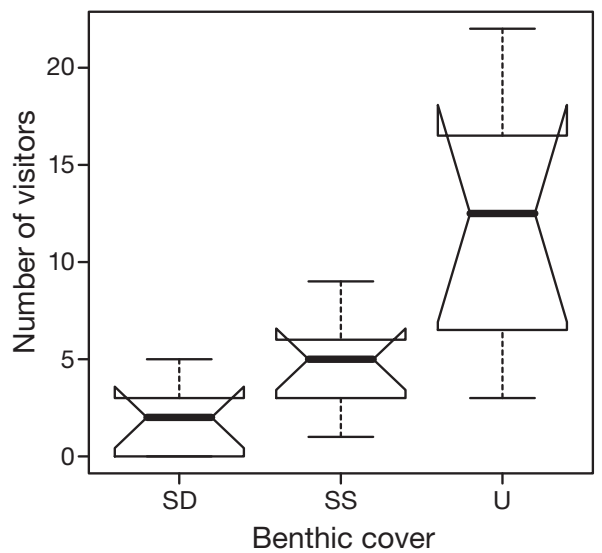

Fig. 3. Box plots of number of fish visitors at bait stations during the first $5 \mathrm{~min}$ at $\mathrm{SD}, \mathrm{SS}$ and $\mathrm{U}$. For habitat type abbreviations, see Fig. 2 
a Individuals
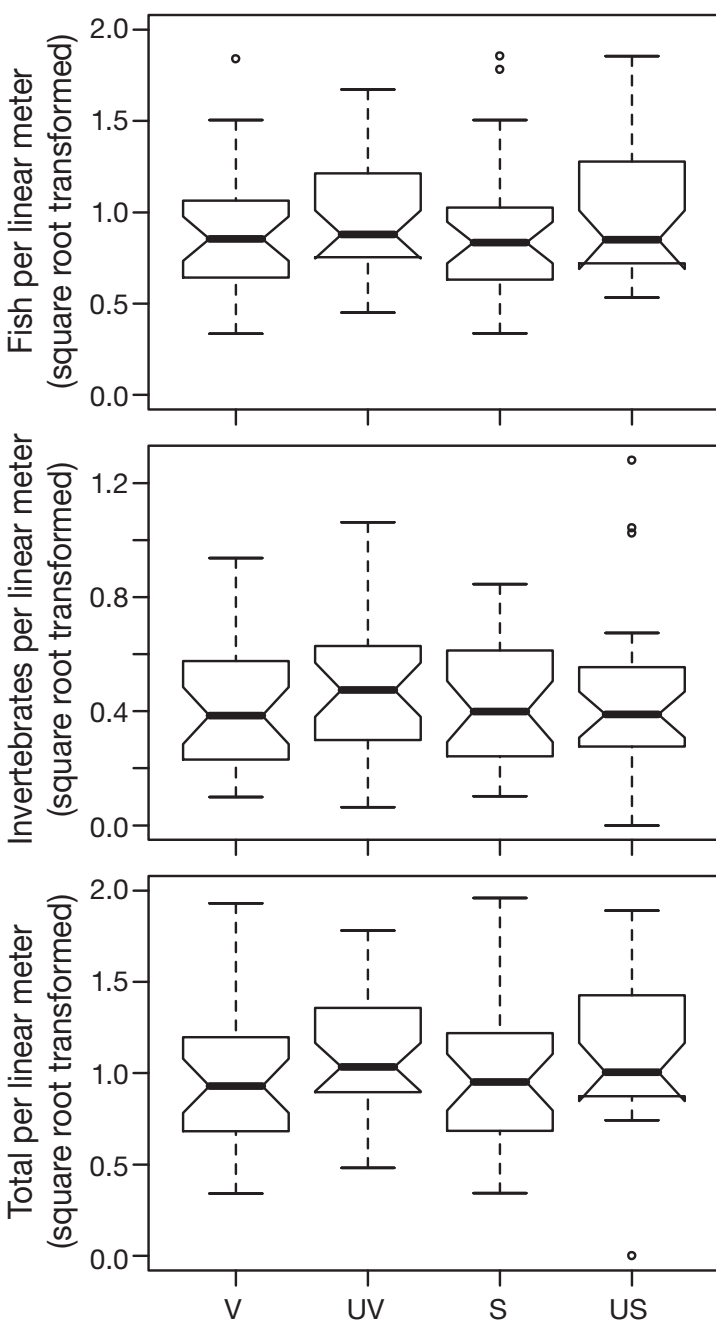

b Groups


Ground cover

Fig. 4. Boxplots of number of (a) individuals or (b) groups per transect meter of habitat type, re-categorized as vegetated (V), unvegetated (UV), structured (S), or unstructured (US)

Taxon diversity showed clearer differences. The R habitat had significantly higher fish diversity than SS or U, which in turn had significantly higher fish diversity than SD or A. SS had signficantly higher invertebrate diversity than $\mathrm{SD}$, $\mathrm{R}$, or $\mathrm{U}$, which had significantly higher invertebrate diversity than $\mathrm{A}$. The diversity difference between SS and U was due entirely to the higher evenness in the former (result not shown), because the richness was identical at 26. Total animal diversity was greatest in R and SS, intermediate in $\mathrm{SD}$ and $\mathrm{U}$, and lowest in $\mathrm{A}$, and these groups were significantly different from each other $(\mathrm{p}<$ 0.001 in all significant comparisons above).

Overall, structured habitats had a higher diversity than unstructured $(p=0.001)$ and unvegetated had a higher diversity than vegetated $(p<0.001)$ habitats. There was no significant overall difference between seagrass and non-seagrass communities $(p=0.56)$.

\section{Species/ground associations}

Nearly half the species censused in the short transects were at least twice as abundant at the nonseagrass sites as at the seagrass sites, while the only species significantly more abundant at the seagrass sites was Zosterisessor ophiocephalus (Fig. 6). The significantly greater abundance at non-seagrass sites for several species was observed in all 3 depth sampling zones, including the shallow algae/rock zone where little or no seagrass occurred at any site and the medium depth zone, which was primarily bare sediment at all sites. Sepia elegans, Symphodus ocellatus, S. roissali, Serranus hepatus, and small Gobidae were all more abundant at non-seagrass sites in the shallow algae/rock zone by factors of 2 to 10 (Fig. 6). In the deepest sampling zone at the western sites, which was 

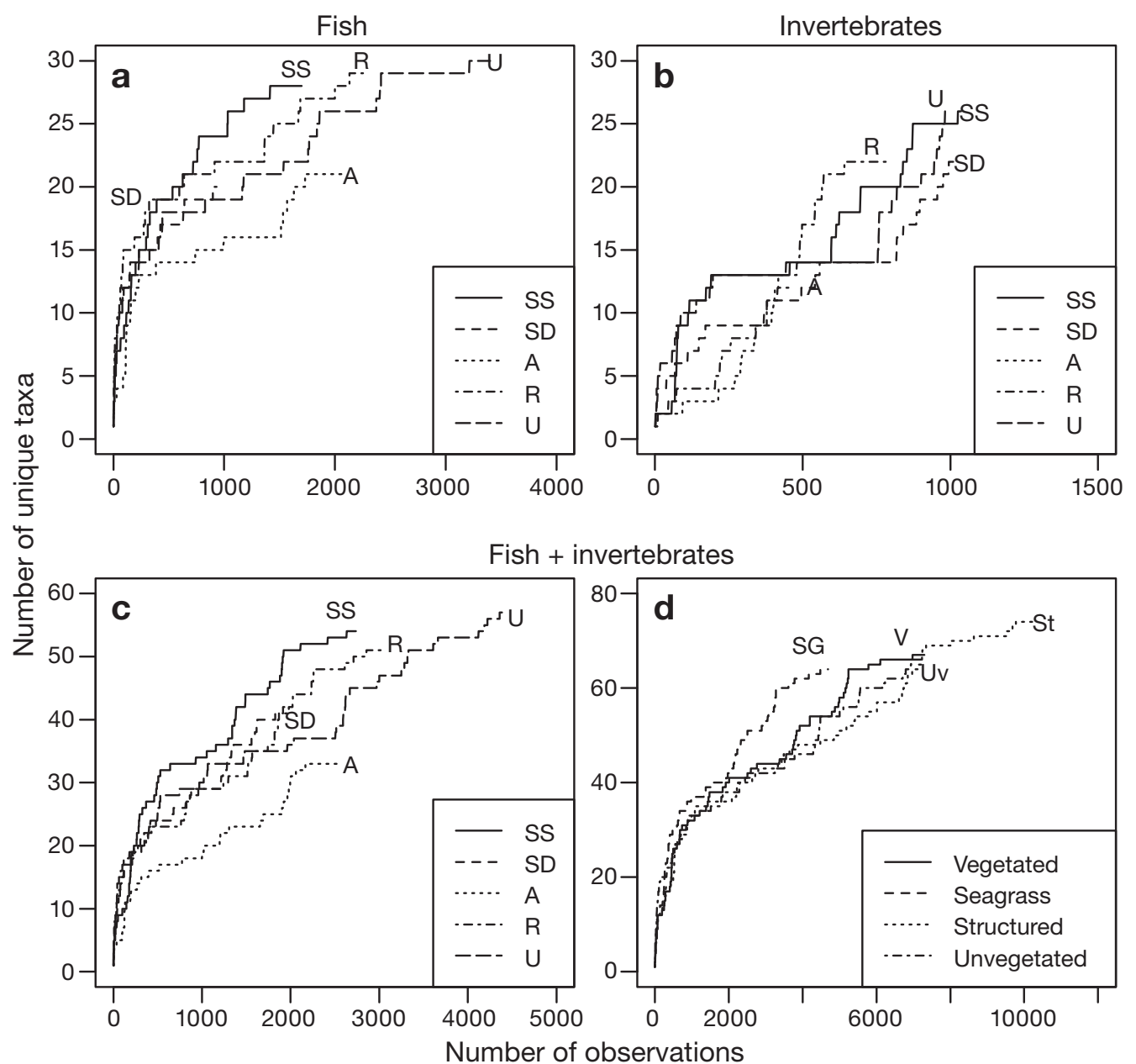

Fig. 5. Taxon richness accumulation curves of (a) fish, (b) invertebrates, (c) fish and invertebrates for the 5 habitat types (A, R, SD, $\mathrm{SS}, \mathrm{U})$, and of (d) fish and invertebrates for the habitat types re-categorized as vegetated (SD, SS, or A), seagrass (SD or SS), structured ( $R, S S, S D$, or A), or unvegetated (R or U). The horizontal axis is the cumulative number of groups observed in chronological order (fall 2006 to fall 2007). For habitat type abbreviations, see Fig. 2

dominated by seagrass, Solea vulgaris, Octopus vulgaris, S. roissali, S. hepatus, Spicara smaris, and Gobidae were more abundant at the non-seagrass sites by factors of 3 to 60 (Fig. 6). Note that, although we found no Anguilla anguilla at the non-seagrass sites, this number was not significantly different $(p=0.20)$ from the 13 individuals seen at seagrass sites (during the short transect census) because of the high among-site variation in the number recorded.

The habitat selection ratio of a taxon for SD was significantly correlated with its abundance ratio at seagrass/non-seagrass sites $\left(R^{2}=0.63, p=0.0001\right.$ for the rank correlation). All species significantly more abundant at non-seagrass sites also avoided SS and $\mathrm{SD}$ at the seagrass sites (Appendix 1), and most showed significant preference for either U (Solea vulgaris, Spicara smaris, Sepia elegans) or A (Symphodus roissali, S. ocellatus) habitats at the western sites (Appendix 1).
Approximately $60 \%$ of the 85 taxa of animals observed in the long transects showed significant positive or negative selection of at least one of the 5 habitats (Appendix 1, Fig. 7). The majority of positive associations were with $\mathrm{U}$ or $\mathrm{R}$ and the majority of negative associations were with $\mathrm{SD}, \mathrm{SS}$ or $\mathrm{A}$. SD had the highest percentage of taxa with negative associations and $\mathrm{U}$ the lowest. Unvegetated ground ( $\mathrm{R}$ or $\mathrm{U}$ ) showed nearly twice the positive associations as vegetated ground (SD, SS or A). In general, about half the positive associations were exclusive to a single habitat type.

\section{Feeding/ground associations}

All substrates were dominated by zoobenthos feeders (result not shown). The incidence of nekton feeding (almost entirely piscivory) was 10 to 27 times greater in 


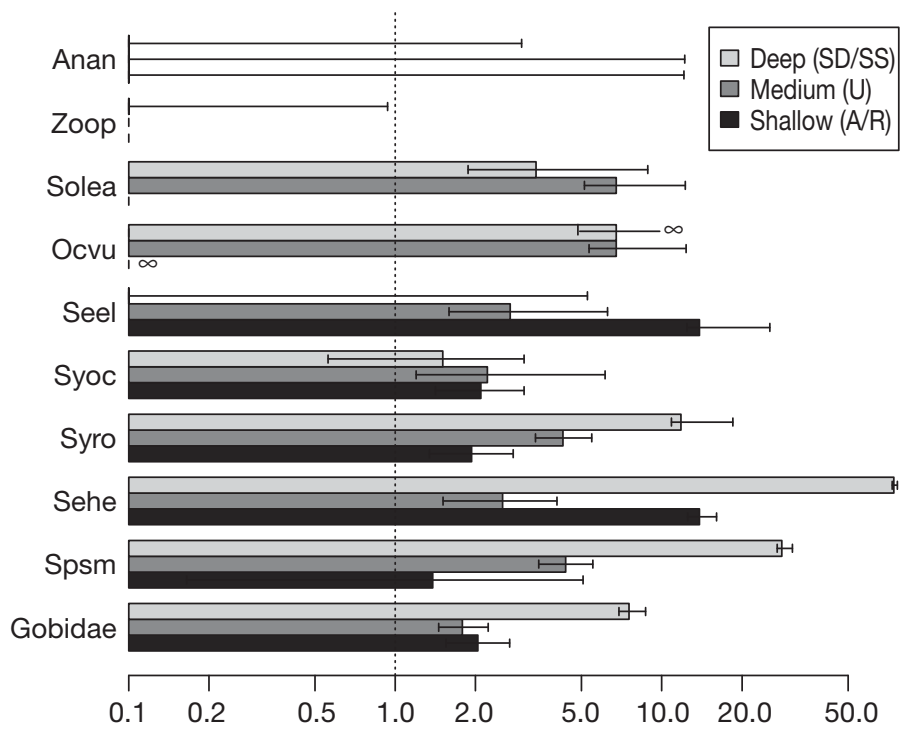

Ratio of mean abundance (non-seagrass : seagrass)

Fig. 6. Relative abundance ratio in the non-seagrass:seagrass sites, repeated for each of the 3 depth zones sampled. Error bars are $95 \%$ confidence intervals based on the range observed in the null distribution of 1000 bootstraps. Shown here are taxa with significantly different abundances at seagrass versus non-seagrass sites ( $X$ in Fig. 1), plus the European eel Anguilla anguilla (Anan). For abbreviations of taxa see Appendix 1

SD or SS than in any other habitat type, and maximal in $\mathrm{SD}\left(\chi_{4}^{2}>100, \mathrm{p}<0.0001\right)$. Zoobenthos feeding was most prevalent in habitat types $\mathrm{U}$ and $\mathrm{R}$, planktivory in $\mathrm{A}$, and herbivory in $\mathrm{R}$ (result not shown).

Within the fish, predators of fish (Anguilla anguilla, Zosterisessor ophiocephalus, Serranus spp.) and their

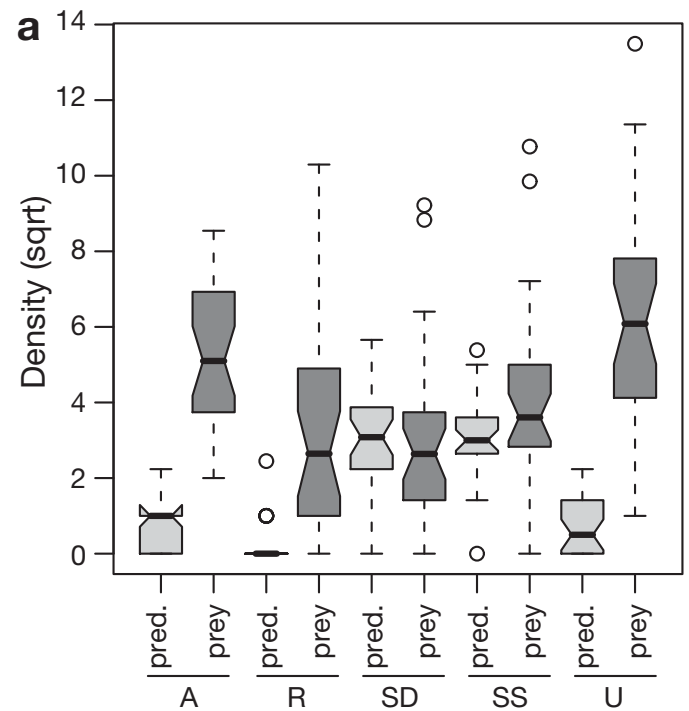

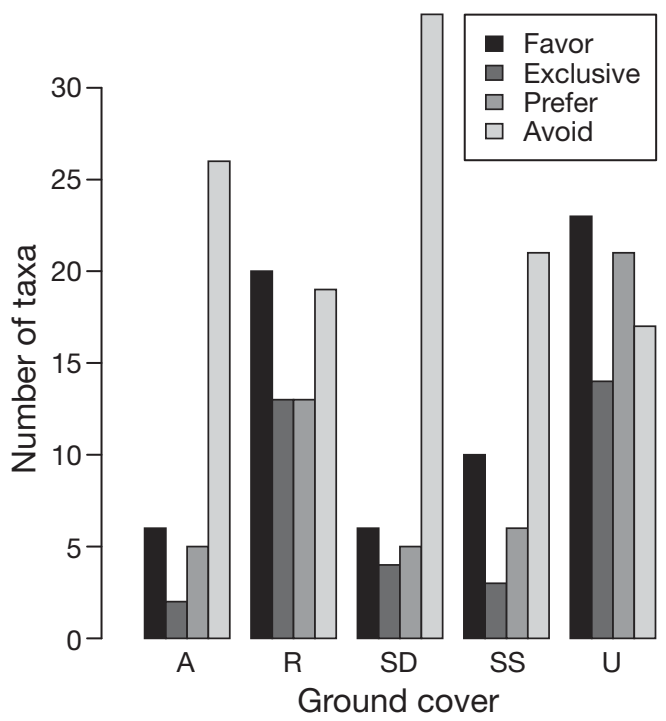

Fig. 7. Number of taxa with significant habitat associations (see Appendix 1). Favor: $\mathrm{R}>1$; Exclusive: $\mathrm{R}=\infty$; Prefer: $\mathrm{R}_{\text {substrate }}=\max (\mathrm{R})$; Avoid: $\mathrm{R}<1$. For habitat abbreviations see Fig. 2

potential prey were very strongly segregated among habitats, with the predators concentrated in SD or SS and their prey concentrated primarily in $\mathrm{U}, \mathrm{R}$, and $\mathrm{A}$ $\left(\chi_{1}^{2}=465, \mathrm{p} \cong 0\right.$ for the Poisson GLM between predator and prey total abundance across habitats, Fig. 8). Fish prey assemblages were significantly negatively correlated with predator assemblage across habitats and sites (Mantel $r=0.191, p=0.01$ ), and the negative effect of total predator abundance on prey assemblages was also significant $\left(F_{1,49}=3.7, p=0.004\right.$ in the permutation test of the MANOVA).

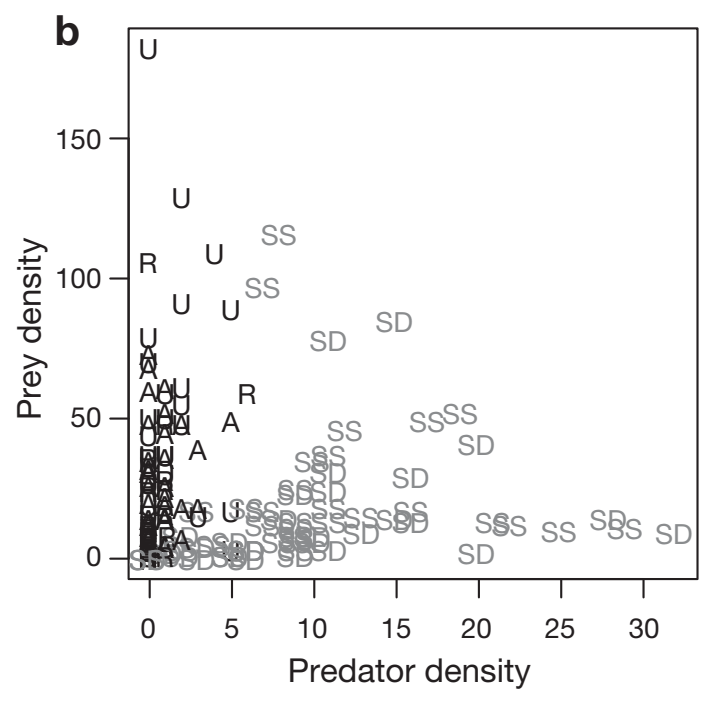

Fig. 8. Habitat segregation (A, R, SD, SS, U) between fish predators and fish prey within the seagrass sites (A to J in Fig. 1). (a) Boxplots of density of predators and prey within each substrate habitat. (b) Plot of prey density against predator density within the indicated substrate habitats. In both cases, replicates are every combination of site and season. Predators include: Zosterisessor ophiocephalus, Anguilla anguilla, and Serranus spp. Prey include: Atherina and all juvenile fish species $<5 \mathrm{~cm}$. For habitat abbreviations see Fig. 2 


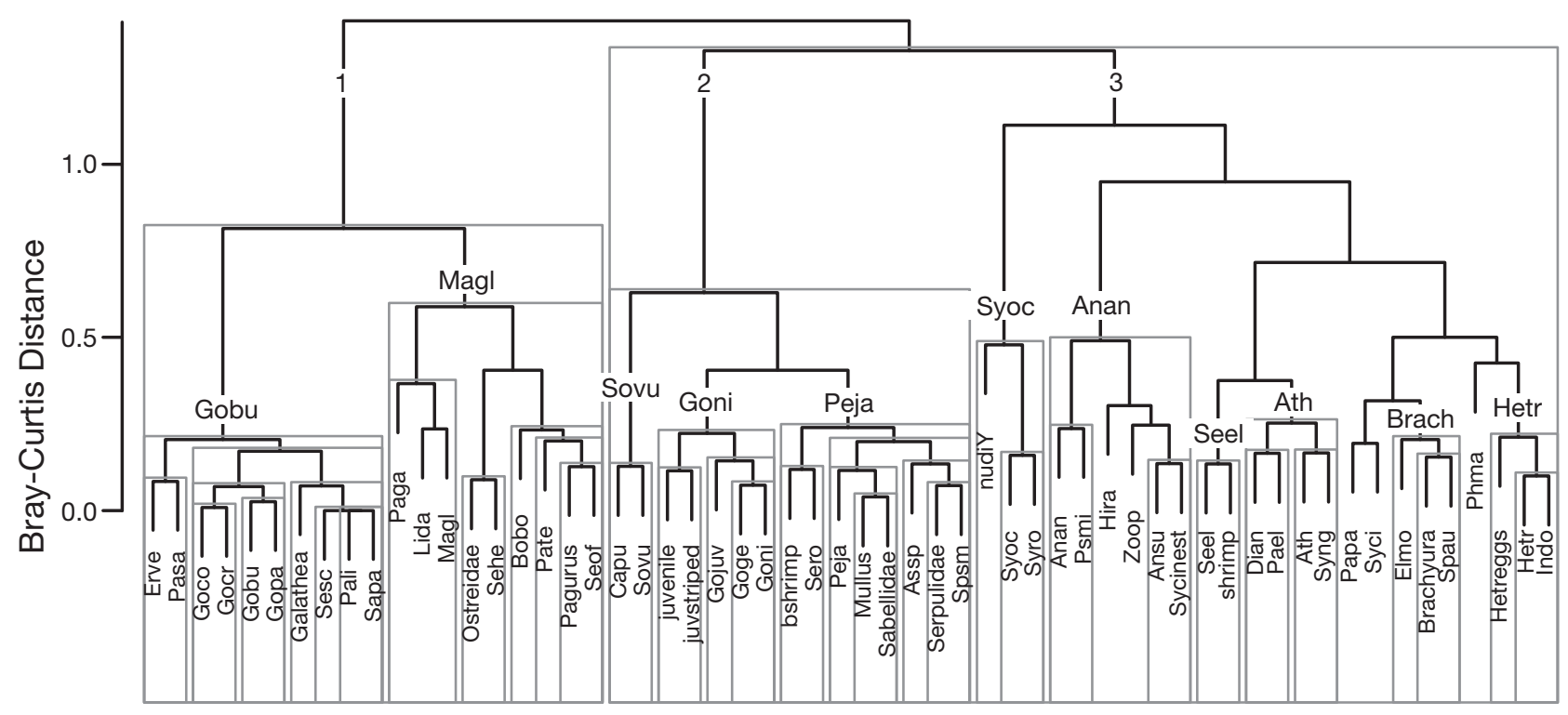

Taxon

Fig. 9. Dendrogram of animal taxa based on their abundance (ind. transect $\mathrm{m}^{-1}$ ) relative to the total within each of the 5 habitats, sampling times and sites pooled. Significant clusters (multiscale bootstrap resampling probability $>0.95$ ) are highlighted in gray rectangles. Each cluster is labeled with the name of the most abundant taxon within (see Appendix 1)

\section{Faunal assemblages}

Substrate type had a very highly significant effect on the faunal assemblage (ANOSIM $\mathrm{R}=0.67, \mathrm{p}<0.001$ ), and assemblages on $\mathrm{A}, \mathrm{R}, \mathrm{U}$, and SD/SS combined were each about equally distinct $(R=0.27$, $\mathrm{p}=0.003 ; \mathrm{R}=0.40, \mathrm{p}<0.001 ; \mathrm{R}=0.15, \mathrm{p}=$ 0.05 ; and $\mathrm{R}=0.32, \mathrm{p}<0.001$, respectively).

The 58 most abundant taxa separated into 3 major branches of species found mainly in habitat type $\mathrm{R}$ (1), $\mathrm{U}$ (2), or SD/SS/A combined (3), which in turn were composed of approximately 11 significant clusters of more than 2 to 3 taxa, each corresponding to a different pattern of association within these branches (Fig. 9).

The detrended correspondence analysis (DCA) biplot showed that relative species abundance was distributed about equally across the habitat types, with each representing a separate, nearly equivalent axis of variation (Fig. 10), a result that is consistent with the presence of distinct species clusters within each of the habitat types (Fig. 9). The 2 major DCA axes correspond roughly to the gradient from unstructured to structured habitat (DCA1) and from $\mathrm{A} / \mathrm{R}$ to SD/SS (DCA2). The 2 axes, however, are nearly equivalent in the amount of variation they encompass, resulting in the difference between the 2 kinds of structure (SD/SS versus A/R, ANOSIM R = $0.21, \mathrm{p}<0.001$ ) being as large or larger than the difference due to presence/absence of structure per se ( $\mathrm{U}$ versus all other habitats, ANOSIM: $\mathrm{R}=0.17, \mathrm{p}<$ 0.001).

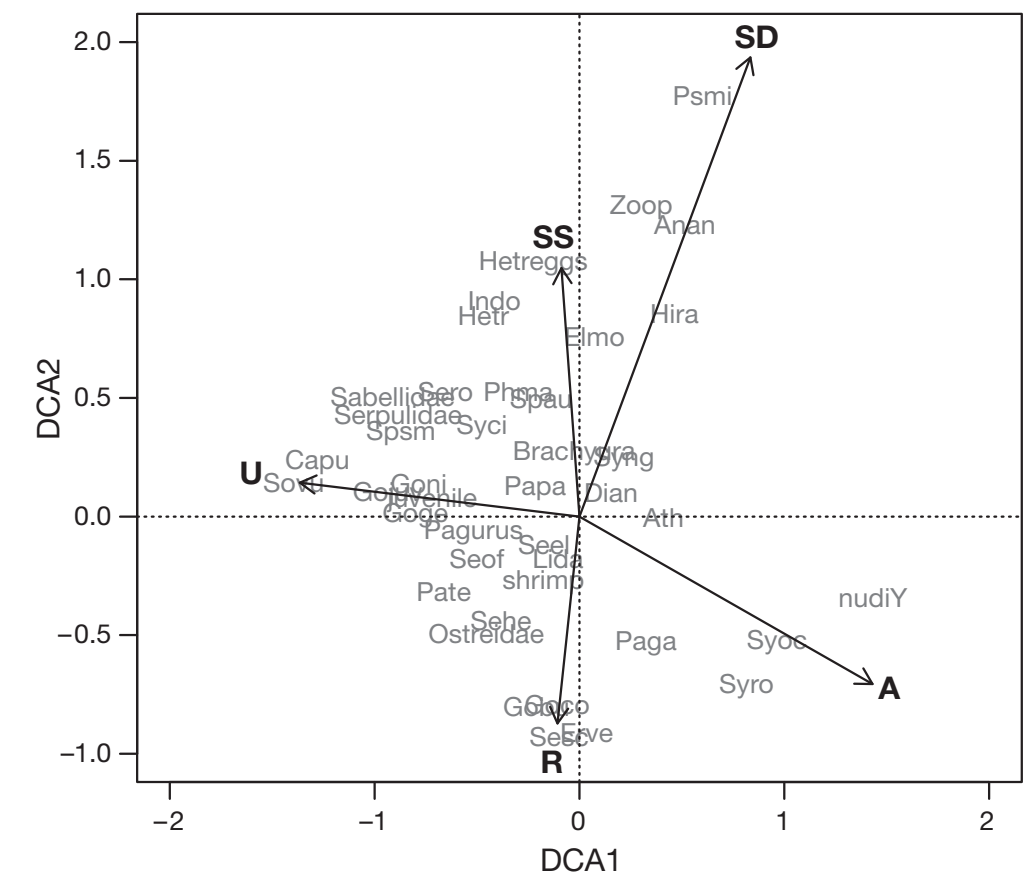

Fig. 10. Detrended correspondence analysis biplot of relative species abundance per transect meter for each of the 5 habitat types as in Fig. 2. Not all taxon names are shown (when 2 names were superimposed, the less abundant taxon was deleted); for abbreviations of taxa see Appendix 1 


\section{DISCUSSION}

\section{Seagrass habitat superiority}

We addressed 2 components of the seagrass habitat superiority (SHS) hypothesis: seagrass meadows provide conditions and resources that (1) increase the fitness and mean density of potential prey species, and (2) increase the total species richness of inhabitant animal communities, both relative to unvegetated substrate (Bell \& Pollard 1989). Our results of visual scuba censuses of over $38 \mathrm{~km}$ of transects across 4 seasons by day and night provide little, if any, support for either component of the SHS for subtidal Zostera noltii, Z. marina, and Cymodocea nodosa meadows and their fish and macroinvertebrate inhabitants in the Novigrad Sea (Figs. 2, 5,6).

The results of the present study imply that the mechanisms responsible for SHS are weak or absent in the Novigrad Sea. Two mechanisms proposed to explain the fitness component of SHS for mobile macrofauna are (1) a lower mortality rate from predation in seagrass meadows (the Heck \& Orth 1980 model), and (2) higher growth and reproduction rates due to higher concentrations of organic matter relative to neighboring unvegetated substrate. Seagrass shoot structure has been shown to provide effective refuge from chase-attack predators by impeding movement and visibility (see references in Horinouchi 2007b). Vegetation, however, is less effective in deterring mortality from other kinds of predatory strategies, such as ambushing or stalking, which can take advantage of concealment allowed by the same structure that hinders chase-attackers (e.g. Laurel \& Brown 2006). One explanation of our results is that mechanism (1) of the SHS is weakened by a high density or efficacy of ambush or stalk-attack predators occupying the seagrass habitat.

\section{Faunal abundance, preference, and feeding behavior}

From the predator's point of view, the strategy of hiding in a food-rich habitat that is attractive to prey ensures a steady supply of prey. If the predator is effective in limiting the prey population within this habitat, then the predicted result is a de facto habitat segregation of the kind we observed.

While assessing predation efficiency was beyond the scope of this study, we found clearly that fish predators were far more abundant in seagrass than in any other habitat; indeed, they were virtually nonexistent at sites lacking seagrass (Figs. 6, 8 \& 10). Two common ambush or stalk-attack predators, the grass goby Zosterisessor ophiocephalus and the European eel Anguilla anguilla, strongly preferred seagrass habitat in the Novigrad Sea and avoided all other substrates (Appendix 1). Both may prefer seagrass because they require soft sediment and shelter for concealing themselves during the day (eel) and to construct mating burrows (grass goby). Both are opportunistic generalist predators in Mediterranean lagoons, feeding on invertebrates and fish (Pagotto \& Campesan, 1980, Bouchereau et al. 2006). The grass goby has 2 capture behaviors, a fast-direct method under bright light and a slower hopping method under dim light (Ota et al. 1999). The goby appears to be adapted to the dimmer conditions of seagrass beds by possessing a high density of retinal rods and cones, and shows no reduction in capture efficiencies or distances under low light intensity (Ota et al. 1999).

The only other potentially major predators of settled fish we encountered were the striped and brown combers (Serranus scriba and S. hepatus), which are ambush and wait predators over rocky substrate (Labropoulou \& Eleftheriou 1997, Labropoulou et al. 1998). Those specimens we encountered, however, were almost certainly too rare and small to have a noticeable impact on fish abundance (Appendix 1). Published literature indicated that, for the most part, the remaining fish species fed on zoobenthos (primarily small crustaceans), plankton, or vegetation, and only rarely on fish, and we found that they favored U, A, or R habitats (Appendix 1). Thus, based on our habitat preference data, it appears that in our study area the habitat type with the highest overall predation risk to fish would be seagrass (SS/SD). Although the relationship between predator and prey density across a landscape can be complex if both are freely mobile (Abrams 2007), prey are expected to be generally less abundant in habitat patches with consistently higher predation risk (Sih 1984, Meager et al. 2005). Our data are consistent with this habitat segregation prediction, as potential prey had significantly lower density within seagrass and significantly favored other substrates (Figs. 8 $\& 9$; Appendix 1), both at a small scale within the seagrass habitat mosaic and over the entire sampling region.

The second major proposed fitness benefit of seagrass habitats, an abundance of easily available, diverse food sources, may become compromised in dense meadows by the severely lowered visibility and freedom of movement (Heck \& Orth 1980). Our results are equivocal on this prediction, since total abundance is highest in dense macroalgae and lowest in dense seagrass (Fig. 2). This difference, however, is consistent with the hypothesis of greater predation intensity in dense seagrass, which has the highest piscivory level of all habitats due to the presence of the European eel (Fig. 8).

\section{Taxon richness and diversity}

The mechanism most often proposed to underly the species richness component of SHS is simply the in- 
crease in niche diversity caused by structural complexity. However, added niches are not profitable if they are little more than feeding stations for ambush predators. If predation limits taxon diversity in seagrass beds, then we would expect that species strongly favoring or preferring seagrass should either be rare or of low value to predators. While it was beyond the scope of the present study to quantify the relative value of the different habitat types or of certain taxa as food sources, none of the species observed to strongly favor or prefer seagrass habitats (significant R > 2) have previously been cited as food items of either the grass goby or the European eel (Riccato et al. 2004, Bouchereau et al. 2006). The species preferring seagrass habitats are the snakelocks anemone Anemonia viridis, the musky octopus Eledone moschata, the banded dye-murex Hexaplex trunculus, the great scallop Pecten jacobaeus, the spiny seastar Marthasterias glacialis, the green urchin Psammechinus microtuberculatus, and the white warty sea squirt Phallusia mammillata (Appendix 1). On the other hand, most of the fish species strongly avoiding seagrass habitats are potential prey of both ambush predators, and their absence contributes to the low species richness and diversity of the SD habitat.

\section{Faunal assemblages}

If animal species in seagrass beds benefit from habitat structure per se, then assemblages should primarily be determined by its presence/absence and secondarily by the morphological details of that structure.

Our results did not support this prediction. Animal assemblages inhabiting habitat type U were more similar overall to SD/SS assemblages than SD/SS assemblages were to other structured habitats such as A or R (see Figs. 9 \& 10). Variation in habitat preference was sharply delineated by structure type, with R- and SD/SS/A-favoring species each forming highly distinct clusters, while U-favoring taxa nested within the SD/SS/A group (Fig. 9, Appendix 1). Overall, each of the habitats appeared to account for an equivalent amount of variation in faunal abundance and was occupied by a stably different species assemblage (Fig. 10).

\section{General applicability of results}

Although our work was confined to a single estuary, our results may be generalizable to shallow subtidal Zostera and Cymodocea beds elsewhere in the Mediterranean. Results from similar research in the northeastern and western Mediterranean are consistent with ours in failing to provide strong support for the SHS hypothesis. In similar mixed Zostera and Cymodocea seagrass beds in the Gulf of Olbia in northeast Sardinia (Italy, western Mediterranean), Guidetti \& Bussotti (2002) reported no difference in total fish abundance or species richness recorded in visual censuses among intact seagrass beds, bare sand, and areas where the entire seagrass canopy was experimentally removed. In the Venice Lagoon (northeast Italy), Franco et al. (2006) found that migrant juvenile fish abundance in seagrass determined with beach seine hauls was less than a tenth of the abundance in neighboring bare substrates or sparsely vegetated ground, and Malavasi et al. (2005) found that smaller gobiids avoided seagrass habitat, while larger gobiids (potentially predators or competitors) preferred seagrass. In visual scuba censuses in the Gulf of Trieste (Slovenian coastline), Bonaca \& Lipej (2005) found that the lowest fish abundances and species richnesses were observed in seagrass beds (Posidonia and Cymodocea) and the highest in algal habitats; no bare sand was studied. In the Pantan estuary (Croatia, mid-eastern Adriatic) Matić-Skoko et al. (2005) observed that species richness and total abundance from beach seine hauls were the same or greater at sites with nearly nonexistent Zostera noltii compared with sites with abundant $Z$. noltii.

The findings from these relatively few studies indicate that strong conclusions concerning the presence, absence, or magnitude of any overall seagrass habitat superiority for fish in shallow subtidal Mediterranean Zostera or Cymodocea beds are currently not possible. While our study and similar studies of nearby localities do not provide support for the Heck \& Orth (1980) model, but rather support a broader predation-mode model, more controlled experiments are necessary to uncover the mechanism for the predator-prey habitat segregation observed (Horinouchi 2007a).

Acknowledgements. We thank 8 anonymous reviewers for their constructive comments on a previous version of the manuscript, and A.J. Underwood and K.R. Clarke for suggestions regarding multivariate statistical techniques. E. Brala, M. Bolic̀, and P. Riel provided much appreciated technical assistance. This work was supported by the University of Zadar, Department of Maritime Science, and by a research grant from the Croatian Ministry of Science for Project 3207 to S.S., Monitoring and ecology of benthic communities of the Croatian Adriatic.

\section{LITERATURE CITED}

Abrams PA (2007) Habitat choice in predator-prey systems: Spatial instability due to interacting adaptive movements. Am Nat 169:581-594

> Anderson MJ (2001) A new method for non-parametric multivariate analysis of variance. Austral Ecol 26:32-46

> Beck MW, Heck KL, Able KW, Childers DL and others (2001) The identification, conservation, and management of estuarine and marine nurseries for fish and invertebrates. Bioscience 51:633-641 
Bell DJ, Pollard DA (1989) Ecology of fish assemblies and fisheries associated with seagrasses. In: Larkum AWD, McComb AJ, Shepherd SA (eds) Biology of seagrasses. Elsevier, Amsterdam, p 565-597

Bell JD, Westoby M (1986) Variation in seagrass height and density over a wide spatial scale. Effects on common fish and decapods. J Exp Mar Biol Ecol 104:275-295

Bonaca MO, Lipej L (2005) Factors affecting habitat occupancy of fish assemblage in the Gulf of Trieste (Northern Adriatic Sea). Mar Ecol 26:42-53

Bouchereau JL, Marques C, Pereira P, Guelorget O, Vergne Y (2006) Trophic characterization of the Prevost lagoon (Mediterranean Sea) by the feeding habits of the European eel Anguilla anguilla. Cah Biol Mar 47:133-142

Cairns AL, Telfer ES (1980) Habitat use by 4 sympatric ungulates in boreal mixedwood forest. J Wildl Manag 44: 849-857

Clarke KR (1993) Nonparametric multivariate analyses of changes in community structure. Aust J Ecol 18:117-143

Costa MJ (1988) Écologie alimentaire des poissons de l'estuarie du Tage. Cybium 12:301-320

> Dauwalter DC, Fisher WL, Belt KC (2006) Mapping stream habitats with a global positioning system: accuracy, precision, and comparison with traditional methods. Environ Manag 37:271-280

Elliott M, Dewailly F (1995) The structure and components of European estuarine fish assemblages. Neth J Aquat Ecol 29:397-417

Franco A, Franzoi P, Malavasi S, Riccato F, Torricelli P, Mainardi D (2006) Use of shallow water habitats by fish assemblages in a Mediterranean coastal lagoon. Estuar Coast Shelf Sci 66:67-83

Froese R, Pauly D (eds) (2000) FishBase 2000: concepts, design and data sources, ICLARM Contribution 1594, ICLARM, Los Baños, Laguna

Gillanders BM (2006) Seagrasses, fish, and fisheries. In: Larkum AWD, Orth RJ, Duarte CM (eds) Seagrasses: biology, ecology, and conservation. Springer, Heidelberg, p 503-536

Gras R, Saint-Jean L (1982) Comments about Ivlev's electivity index. Rev Hydrobiol Trop 15:33-37

Gray CA, Chick RC, McElligott DJ (1998) Diel changes in assemblages of fishes associated with shallow seagrass and bare sand. Estuar Coast Shelf Sci 46:849-859

Guidetti P, Bussotti S (2002) Effects of seagrass canopy removal on fish in shallow Mediterranean seagrass (Cymodocea nodosa and Zostera noltii) meadows: a local-scale approach. Mar Biol 140:445-453

Heck KL, Orth LM (1980) Seagrass habitats: the role of habitat complexity, competition and predation in structuring associated fish and motile macroinvertebrate assemblages. In: Kennedy VS (ed) Estuarine perspectives. Academic Press, New York, p 449-464

Heck KL, Orth LM (2006) Predation in seagrass beds. In: Larkum AWD, Orth RJ, Duarte CM (eds) Seagrasses: biology, ecology, and conservation. Springer, Heidelberg, p 537-550

Heck KL, Hays G, Orth RJ (2003) Critical evaluation of the nursery role hypothesis for seagrass meadows. Mar Ecol Prog Ser 253:123-136

Hill MO (1973) Diversity and evenness. Unifying notation and its consequences. Ecology 54:427-432

Hindell JS, Jenkins GP (2005) Assessing patterns of fish zonation in temperate mangroves, with emphasis on evaluating sampling artefacts. Mar Ecol Prog Ser 290:193-205

Horinouchi M (2007a) Distribution patterns of benthic juvenile gobies in and around seagrass habitats: Effectiveness of seagrass shelter against predators. Estuar Coast Shelf Sci 72:657-664
Horinouchi M (2007b) Review of the effects of within-patch scale structural complexity on seagrass fishes. J Exp Mar Biol Ecol 350:111-129

> Horinouchi M, Nakamura Y, Sano M (2005) Comparative analysis of visual censuses using different width striptransects for a fish assemblage in a seagrass bed. Estuar Coast Shelf Sci 65:53-60

Jackson EL, Rowden AA, Attrill MJ, Bossey SJ, Jones MB (2001) Importance of seagrass beds as a habitat for fishery species. In: Barnes M, Gibson R (eds) Oceanography and Marine Biology, Vol 39. Taylor \& Francis, London, p 269-303

La Mesa G, Di Muccio S, Vacchi M (2006) Abundance, size distribution and habitat preferences in the grouper assemblage of the Ustica marine reserve (SW Mediterranean). Cybium 30:365-377

Labropoulou M, Eleftheriou A (1997) The foraging ecology of 2 pairs of congeneric demersal fish species: Importance of morphological characteristics in prey selection. J Fish Biol 50:324-340

> Labropoulou M, Tserpes G, Tsimenides N (1998) Age, growth and feeding habits of the brown comber Serranus hepatus (Linnaeus, 1758) on the Cretan shelf. Estuar Coast Shelf Sci 46:723-732

Larkum WD, Orth RJ, Duarte CM (2006) Seagrasses: biology, ecology and conservation. Springer, Heidelberg

Laurel BJ, Brown JA (2006) Influence of cruising and ambush predators on 3-dimensional habitat use in age 0 juvenile Atlantic cod Gadus morhua. J Exp Mar Biol Ecol 329:34-46

Legendre P, Legendre L (1998) Numerical ecology. Elsevier, Amsterdam

Malavasi S, Franco A, Fiorin R, Franzoi P, Torricelli P, Mainardi D (2005) The shallow water gobiid assemblage of the Venice Lagoon: abundance, seasonal variation and habitat partitioning. J Fish Biol 67:146-165

Matić-Skoko S, Peharda M, Pallaoro A, Franićević M (2005) Species composition, seasonal fluctuations, and residency of inshore fish assemblages in the Pantan estuary of the eastern middle Adriatic. Acta Adriat 46:201-212

Matić-Skoko S, Peharda M, Pallaoro A, Cukrov M, Bazdaric B (2007) Infralittoral fish assemblages in the Zrmanja estuary, Adriatic sea. Acta Adriatica 48:45-55

Meager JJ, Williamson I, Loneragan NR, Vance DJ (2005) Habitat selection of juvenile banana prawns, Penaeus merguiensis de Man: Testing the roles of habitat structure, predators, light phase and prawn size. J Exp Mar Biol Ecol 324:89-98

Miller PJ 1986. Gobiidae. In: Whitehead PJP, Bauchot ML, Hureau J-C, Nielsen J, Tortonese E (eds) Fishes of the north-eastern Atlantic and the Mediterranean. Vol. 3, p 1019-1085. UNESCO, Paris

Nagelkerken I, Dorenbosch M, Verberk W, Cocheret de la Moriniére E, van der Velde G (2000) Importance of shallow-water biotopes of a Caribbean bay for juvenile coral reef fishes: patterns in biotope association, community structure and spatial distribution. Mar Ecol Prog Ser 202:175-192

Norris JG, Wyllie-Echeverria S, Mumford T, Bailey A, Turner $T$ (1997) Estimating basal area coverage of subtidal seagrass beds using underwater videography. Aquat Bot 58: 269-287

> Orth RJ, Heck KL, Vanmontfrans J (1984) Faunal communities in seagrass beds. A review of the influence of plant structure and prey characteristics on predator prey relationships. Estuaries 7:339-350

Ota D, Francese M, Ferrero EA (1999) Vision in the grass goby, Zostericessor ophiocephalus (Teleostei, Gobiidae): a morphological and behavioural study. Ital J Zool 66: 125-139 
Pagotto G, Campesan G (1980) Food habits of certain fish of the Venice Lagoon Italy Zosterisessor ophiocephalus Pisces Gobiidae in the adult stage. Atti Mus Civ Stor Nat Trieste 32:1-18

Palmer MW (1990) The estimation of species richness by extrapolation. Ecology 71:1195-1198

Rhodes JR, McAlpine CA, Lunney D, Possingham HP (2005) A spatially explicit habitat selection model incorporating home range behavior. Ecology 86:1199-1205

Ribeiro J, Bentes L, Coelho R, Goncalves JMS, Lino PG, Monteiro P, Erzini K (2006) Seasonal, tidal and diurnal changes in fish assemblages in the Ria Formosa lagoon (Portugal). Estuar Coast Shelf Sci 67:461-474

Riccato F, Franco A, Franzoi P, Fiorin R, Malavasi S, Torricelli $P$ (2004) Influence of age and habitat type on the dietary composition of Zostericessor ophiocephalus in the Venice
Lagoon. Biol Mar Medit 11:617-619

Schultz ST (2008) Seagrass monitoring by underwater videography: disturbance regimes, sampling design, and statistical power. Aquat Bot 88:228-238

Sih A (1984) The behavioral-response race between predator and prey. Am Nat 123:143-150

Sinovćić G, Franicević M, Keć VC (2004) Unusual occurrence and some aspects of biology of juvenile gilt sardine (Sardinella aurita Valenciennes, 1847) in the Zrmanja River estuary (eastern Adriatic). J Appl Ichthyol 20:53-57

Solana-Sansores R (2001) Spatial patterns of the epipelagic species caught incidentally in the tuna fishery on floating objects, in the eastern Pacific Ocean. Cienc Mar 27:445-479

Suzuki R, Shimodaira H (2006) Pvclust: an R package for assessing the uncertainty in hierarchical clustering. Bioinformatics 22:1540-1542

Appendix 1. Habitat selection ratios R in video/DPGS study. Abbrev: abbreviation for taxon used in dendrograms; $\mathbf{A}, \mathbf{R}, \mathbf{S D}, \mathbf{S S}, \mathbf{U}$ : association ratio $\mathrm{R}$ for the respective substrate, equal to the probability ratio of occupation to non-occupation of a small segment of the indicated substrate, all sites and sampling times pooled. Asterisks indicate a statistically significant departure of the ratio from one at ${ }^{*} p=0.05,{ }^{* *} p=0.01$, or ${ }^{* * *} p=$ 0.001. P: substrate is included in the habitat commonly used by the taxon according to FishBase (Froese \& Pauly 2000). $\infty:$ taxon only observed on that substrate. Chisq and Prob: chi-square $(\mathrm{df}=1)$ and associated probability for the overall test of association across all substrates; Inds and Gps: total number of individuals and groups observed of the taxon throughout the long transect study

\begin{tabular}{|c|c|c|c|c|c|c|c|c|c|c|}
\hline Abbreviation & Taxon & A & $\mathrm{R}$ & $\mathrm{SD}$ & SS & $\mathrm{U}$ & Chisq & Prob & Inds & Gps \\
\hline & CNIDARIA & & & & & & & & & \\
\hline Ansu & Anemonia viridis & $0.11^{* * *}$ & $0.35^{* * *}$ & $3.61^{* * *}$ & $1.33^{*}$ & $0.34^{* * *}$ & 168.2 & $<0.001$ & 276 & 254 \\
\hline Sero & Sepiola rondoletti & $0^{*}$ & 0.4 & 0.45 & 1.4 & $3.6^{* *}$ & 13 & 0.011 & 16 & 16 \\
\hline Seof & Sepia officinalis & 0.61 & 1.51 & $0^{*}$ & 0.77 & $3.6^{*}$ & 6.5 & 0.165 & 12 & 10 \\
\hline \multirow{3}{*}{ Elmo } & Eggs of Loligo vulgaris & 0 & $\infty^{*}$ & 0 & 0 & 0 & 5.8 & 0.217 & 17 & 1 \\
\hline & Loligo vulgaris & 5.52 & 0 & 3.13 & 0 & 0 & 4 & 0.41 & 9 & 2 \\
\hline & Gastropoda & & & & & & & & & \\
\hline \multirow[t]{3}{*}{ nudiY } & Unid. yellow nudibranch & $22.09^{* * *}$ & $0^{* * *}$ & $0.78^{* * *}$ & $0^{* * *}$ & $0^{* * *}$ & 120.8 & $<0.001$ & 258 & 30 \\
\hline & Aplysia punctata & 0 & 0 & $\infty$ & 0 & 0 & 3.3 & 0.515 & 1 & 1 \\
\hline & Dendrodoris limbata & 0 & 0 & 0 & $\infty$ & 0 & 2.7 & 0.606 & 1 & 1 \\
\hline & SIPUNCULA & & & & & & & & & \\
\hline worm & Prob. Sipunculida & $0^{*}$ & 0 & $0^{*}$ & $0^{* *}$ & $\infty^{* * *}$ & 35.9 & $<0.001$ & 37 & 8 \\
\hline & ANNELIDA & & & & & & & & & \\
\hline Sabellidae & Sabellidae & 0 & $0^{* *}$ & 0 & 2.06 & $5.39^{*}$ & 13.3 & 0.01 & 65 & 10 \\
\hline \multirow[t]{2}{*}{ Serpulidae } & Serpulidae & $0^{* * *}$ & $0.22^{* *}$ & $0.11^{*}$ & 1.39 & $5.9^{* * *}$ & 32.9 & $<0.001$ & 213 & 29 \\
\hline & CRUSTACEA & & & & & & & & & \\
\hline Brachyura & Mostly Carcinus mediterraneus & $0.61^{* * *}$ & $1.34^{* * *}$ & $0.54^{* * *}$ & $1.68^{* * *}$ & $1.01^{*}$ & 120.9 & $<0.001$ & 993 & 713 \\
\hline Erve & Eriphia verrucosa & 0.5 & $66.27^{* * *}$ & 0 & $0^{* *}$ & $0^{* *}$ & 36.7 & $<0.001$ & 11 & 11 \\
\hline Galathea & Galathea & 0 & $65.95^{* * *}$ & $0^{*}$ & 0.28 & $0^{*}$ & 26.2 & $<0.001$ & 12 & 12 \\
\hline bshrimp & Prob. Processa & $0^{*}$ & $0^{*}$ & 0.48 & 1.54 & $4.12^{* *}$ & 14.9 & 0.005 & 37 & 15 \\
\hline Pael & Palaemon elegans & $2.31^{* * *}$ & $2.04^{* * *}$ & $0.68^{* * *}$ & $0.5^{* * *}$ & $0.56^{* * *}$ & 262.7 & $<0.001$ & 5012 & 1076 \\
\hline shrimp & Prob. juvenile Palaemon & $1.88^{* * *}$ & $1^{* * *}$ & $0^{* *}$ & $0.27^{* * *}$ & $3.96^{* * *}$ & 44.7 & $<0.001$ & 398 & 63 \\
\hline
\end{tabular}


Appendix 1 (continued)

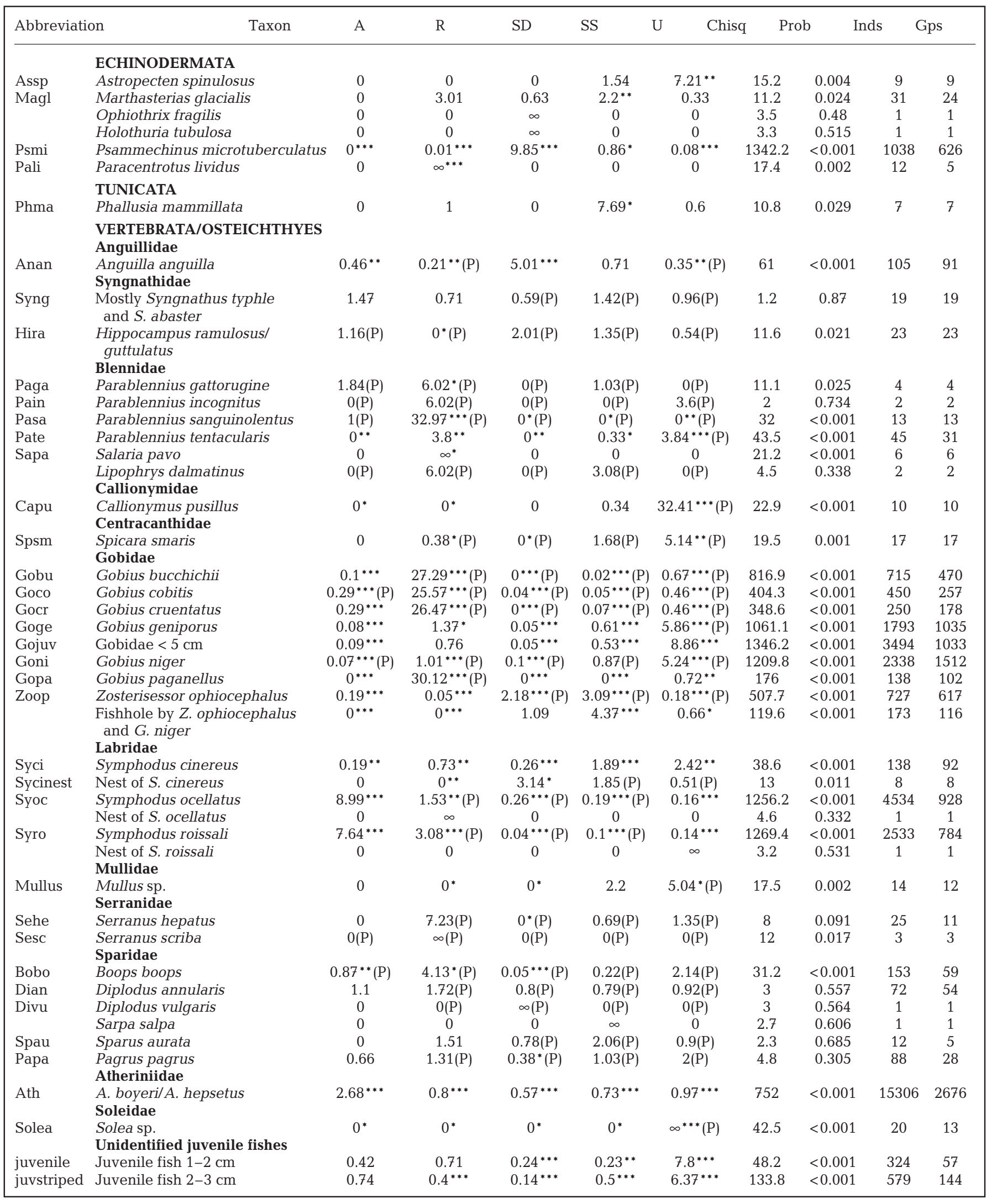

